\title{
A Bugaci-mintaterület felszíni, felszínközeli üledékeinek geokémiai vizsgálata
}

\author{
*FÜGEDI Ubul, KERÉK Barbara, KUTI László, HALUPKA Gábor \\ Magyar Bányászati és Földtani Szolgálat, Budapest \\ Alkalmazott és Környezetföldtani Osztály \\ (Beérkezett: 2018.05.02.; Elfogadva: 2019.05.19)
}

\section{Bevezetés}

A Magyar Állami Földtani Intézetben az 1980-as évek elején indítottuk el agrogeológiai mintaterületi kutatási programunkat, mert a földtani térképezési tapasztalataink rámutattak, hogy szükség van olyan viszonylag kis kiterjedésü, meghatározott felépítésủ területek vizsgálatára, ahol egy-egy problémát tudunk célirányosan, részletesen megkutatni. A kutatás lényege, hogy különböző (pl. földtani, talajtani, mezögazdasági, környezetvédelmi) szempontok alapján kiválasztott kisebb $\left(\max .50 \mathrm{~km}^{2}\right)$ területeket sürün, általában négyzetháló mentén telepített, max. 10 m-es mélységü sekélyfúrásokkal feltárunk, és az így nyert mintaanyagot laboratóriumban részletesen megvizsgáljuk (KUTI. 2009) Terveinkben szerepelt az is, hogy egy-egy kiválasztott területet 5-10 év elteltével újra föltárunk, hogy az esetleges időbeli változásokat megfigyelhessük, s megmagyarázhassuk. Ennek a programnak egyik eleme a Bugaci-mintaterület.

A $49 \mathrm{~km}^{2}$-es Bugaci-mintaterületet a névadó falutól nyugatra jelöltük ki úgy, hogy nyugaton elérje az ősborókás keleti peremét. A területet, illetve részeit négyszer tártuk fel max. $10 \mathrm{~m}$ mély sekélyfúrásokkal:

- 1988-ban 87 fúrás teljes rétegsorát mintáztuk szedimentológiai vizsgálatra, továbbá a Bartha-Fügedi-Kuti (BFK) szintekből (BARTHA, FÜGEDI, KUTI, 1991; KUTI, TULLNER, 1994) geokémiai vizsgálatra is vettünk mintát.

- 1998-99-ben a 90 fúrás többségéböl csak a BFK szinteket mintáztuk. Részletes szedimentológiai vizsgálatot csak abból a három fúrásból kértünk, amelyeket az első alkalommal nem tudtuk lemélyíteni, de geokémiai vizsgálat minden mintából készült;

- 2000-ben a jellegzetes rétegsorok jellemzésére 5 lyukat újrafúrtunk 17-20 mintával szedimentológiai, röntgen- és termoanalitikai vizsgálatokra;

- 2002-ben 26, maximum 1 méteres furatot mélyítettünk a növényzet és a felszíni képződmények kapcsolatának vizsgálatára. Szedimentológiai vizsgálat 20 furatból készült.

A sekélyfúrásokat a mintaterület középső részén $500 \mathrm{~m} * 500 \mathrm{~m}$, a széleken $1000 \mathrm{~m} * 1000 \mathrm{~m}$ ponttávolsággal telepítettük.

Sajnos, a két mintasort a geokémiai vizsgálatra különböző reagensekkel tárták föl, ezért eredményeik nem vethetők össze.

*Levelezö szerzö: FüGEDI UBUL, Magyar Földtani és Geofizikai Intézet,

1134 Budapest, Stefánia út 14.

E-mail: pasteurperc@gmail.com 
A korábbi eredményeket KeréK B. (2003) összesítette, ö dolgozta fel a szemcsevizsgálatokat és a talajvízelemzéseket is. Vizsgálatai részeredményeit több publikációban (KerÉK, KUTI， VATAI，2002; KUTI，ZENTAY， KeréK，2002) jelentette meg. Az elkészült vizsgálatsorból az 1998-99-es felvétel nyomelemadatai maradtak értelmezetlenek; ezt a hiányosságot jelen munkánkkal pótoljuk.

Terjedelmi okokból jelen publikációnkban az alapadatok és a korrelációs táblák többségét nem közöljük. Ezek nyilvánosak; kérésre (Magyar Bányászati és Földtani Szolgálat Alkalmazott és Környezetföldtani Osztályán) hozzáférhetőek.

\section{A mintaterület geomorfológiai, földtani jellemzői}

Az Alföldön a felszín közelében a mikroelemek viselkedését alapvetően két tényező határozza meg: a terület általános geokémiai jellege és a felszíni, leszálló, illetve felszín alatti, ingadozó víz.

A Bugaci-mintaterület a Duna-Tisza-közi homokhátság középső, futóhomokos részén helyezkedik el (1. ábra). Arculatát az ÉNy-DK-i irányú homokbuckák és a köztük kialakult laposok jellemzik.

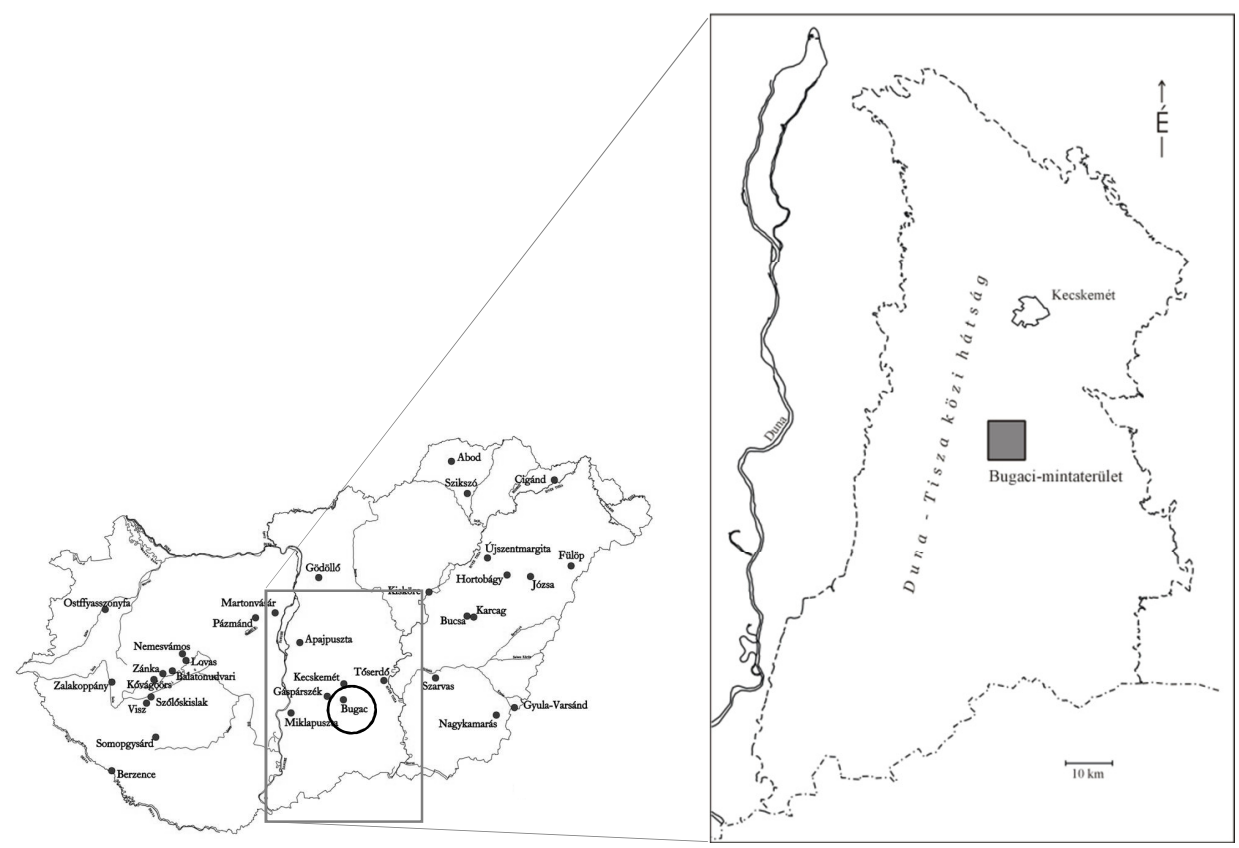

\section{1. ábra}

A mintaterület elhelyezkedése

A Bugaci-mintaterületen - annak alapvetően eolikus, buckás jellege miatt időszakos elöntésekkel csak az északi perem közelében a homokbuckák közötti laposokban kialakult szikes tavakban (Kis-Széki-tó, Kerek-tó, Fekete-szék, 
Mangalica-szék és három kicsi, elnevezetlen lapos) kell számolni; ez a gyakorlatban egyetlen fúrás (az 1005-ös) elemháztartását befolyásolhatja.

Mintaterületünk felszínén összesen kétféle földtani képződmény fordul elő:

- a buckákon futóhomok;

- a laposok felszínén agyagos-finomkőzetlisztes üledék.

A homok zömét a Duna árteréről halmozta át ide a szél. Korábbi földtani térképezési megfigyeléseink egyértelműen bizonyították, hogy a Duna-Tisza közi hátságon a futóhomok a Würm hideg, száraz szakaszaiban mozgott és rakódott le, a kissé enyhébb interstadiálisokban pedig a lösz halmozódott fel. Ezt erősítették meg UJHÁZY K., GÁBRIS Gy., FRECHEN, M. (2003) kutatási eredményei is, miszerint az óholocén szárazabb periódusaiban már csak kisebb homokfoltok mozoghattak. A nedvesebb, kevésbé hideg periódusokban - így a késő glaciális interstadiálisaiban a homok felszínét növényzet borította. Ez kiváló lehetőséget nyújtott a finomabb szemcseméretủ eolikus üledék megkötődésére, és ezzel löszrétegek kialakulására. A buckák közötti vizenyős laposok tavacskáiban is finomszemcsés üledékek halmozódtak föl.

A terület gyakorlatilag lefolyástalan; a két csatorna (Kelö-éri-csatorna, Bócsabugaci-csatorna) vízszállítása napjainkban elhanyagolható. Ennek megfelelően a beszivárgó víz többsége a felszín alatt kis, lokális áramlási rendszerekben a buckáktól a laposok felé mozog, és közben bepárlódik. Ennek megfelelően a laposok alatt a víz sótartalma lényegesen nagyobb, mint a buckák alatt. Ez zömmel a jó elektrolitok felszaporodásának köszönhető: a buckák alatt (így a terület nagyobb részén) a talajvíz jellemzően kalcium-hidrogénkarbonátos; a nátrium és a szulfát a laposok és kiváltképpen a szikes tavak alatt meghatározó. A talajvíz jellemző mélysége a laposokban 1-2 méter, a buckák alatt $>4 \mathrm{~m}$, a terület déli-délnyugati részén, egy több négyzetkilométeres folton $>10 \mathrm{~m}$. A talajvíz szintje az 1980-as évek elejétől 1995-ig a vízelvezető csatornahálózat kiépítése és a terület (mezö- és erdőgazdasági) hasznosításának változásai miatt erőteljesen süllyedt, majd 1995-től 2003-ig kissé emelkedett.

A buckák anyaga pleisztocén futóhomok; a laposokon, az időszakos tavak medrében agyagos-kőzetlisztes homok. A homok közé több helyen is kőzetlisztes rétegek-lencsék települnek; a homok túlsúlya erőteljes (homok 74\%, löszös homok $5 \%$, lösz $12 \%$, tavi üledék $9 \%$ ). A felszíni és felszínközeli képződményeket részletesebben KERÉK B. (2003) mutatta be.

A homok szélfútta jellegéből adódóan a földtani időben se a buckák, se a közöttük kialakult laposok helyzete nem állandó: a tavi üledékek alatt rendszeresen homok települ, a homok közé rendszeresen kőzetlisztes, illetve agyagos-kőzetlisztes lencsék települnek. Mind a recens, mind a fosszilis (eltemetett) tavi üledékek jelentős része (30-50\%-a) karbonátiszap; ennek kiválását és átalakulását MoLNÁR (MOLNÁr 1980; MOLNÁR, SZÓNOKY \& KOVÁCS, 1981; MOLNÁR, BOTZ, 1996; MOLNÁR, SCHNEIDER-LÜPKES, 2001) tanulmányozta a legrészletesebben. 
A kőzetliszt méretü, szélfútta anyag egy része kristályos karbonátásvány (kalcit, illetve dolomit). A karbonátszemcséket a jégkorszakban, a Dunántúliközéphegységből fújta ide a szél (FÜGEDI, SZURKOS, VERMES, 2005, FÜGEDI, et al., 2008b). A sekély áramlási rendszerekben a kristályos karbonát apránként beoldódik (FÜGEDI, et al.,2008a), és az oldott anyag a talajvíz szintje fölött legfeljebb 1,5-2 méterrel (VÁRALLYAY 1967, TÓTH, SZENDREI, 2006;) kialakuló mészakkumulációs szintekben csapódik ki.
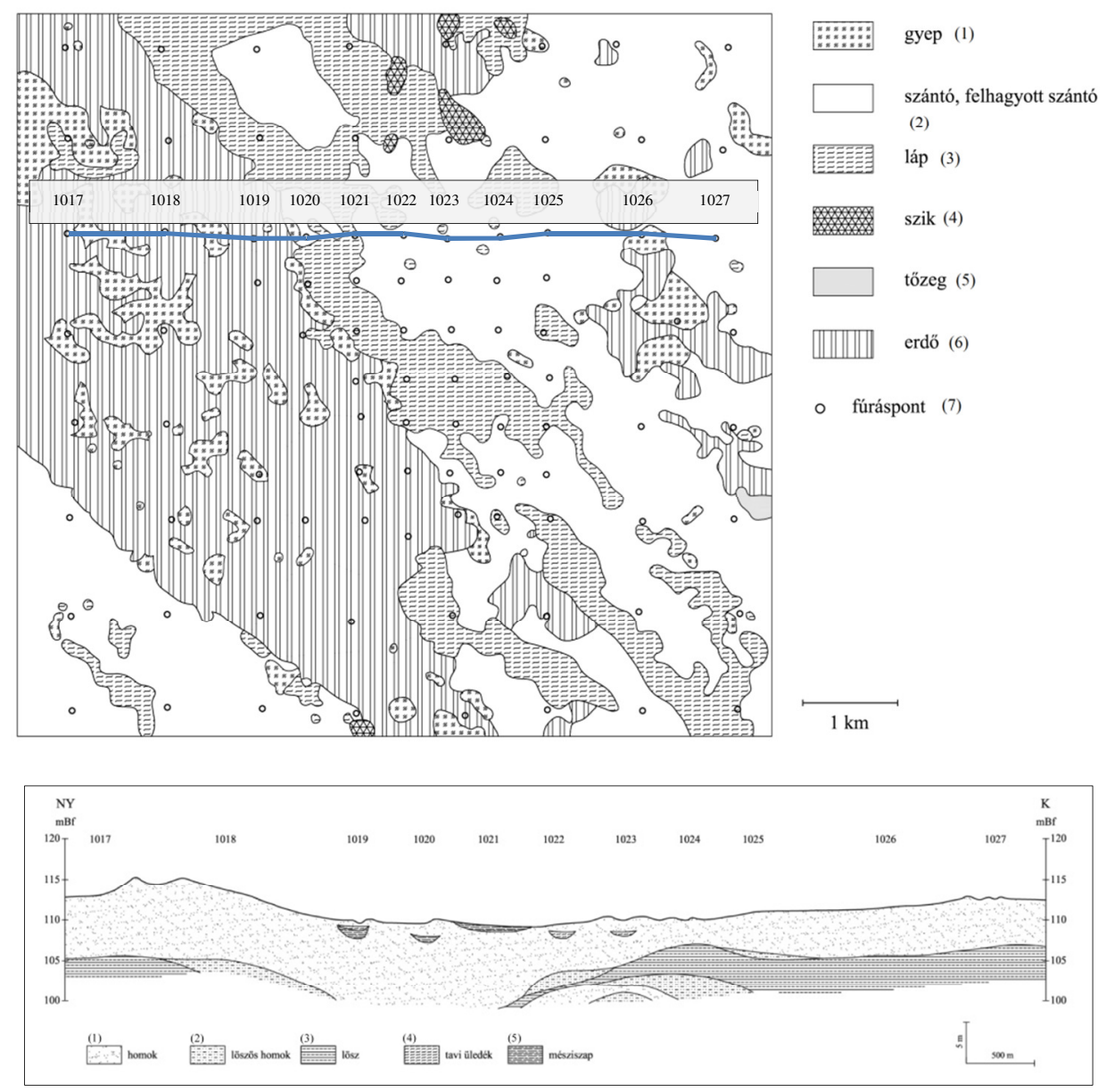

2. ábra

A mintaterület a fúráshálóval és a földtani szempontból kiemelt vegetáció típusokkal, valamint a földtani felépítést mutató, jellemző keresztszelvénnyel (ábrázolás: Hermann Viktor) A keresztszelvény nyomvonalát a mintaterületi vázlaton jelöltük. 


\section{Mintavétel}

A szelvényeket spirálfúróval tártuk fel. A ponyvára kiterített anyagot a helyszínen makroszkóposan rétegre tagoltuk és leírtuk, majd megmintáztuk.

Szedimentológiai vizsgálatra rétegváltásonként, de $2 \mathrm{~m}$-ig legalább $0,5 \mathrm{~m}$ enként, $2 \mathrm{~m}$ alatt méterenként vettünk mintákat. A nyomelem-vizsgálatokra szánt mintákat pontszerüen, a mintaterületi kutatásainkhoz kidolgozott BFK módszer szerint gyüjtöttük be (BARTHA, FÜGEDI, KUTI, 1991). Azaz mintát vettünk a talaj szintjéből (A minta), a talajképző üledékből (B minta), a talajvíz ingadozási zónájából (C minta), az állandóan víztelített zónából (D minta) és a talajvízből. Eredetileg a talajszintből csak egy mintát vettünk, később az MTA ATK Talajtani és Agrokémiai Intézet szakembereinek javaslatára a talaj „A” szintjét két, a talaj felső és alsó szintjéből vett mintára (A1, A2) bontottuk.

Mivel a csapadék- és tápanyagszegény, gyér növényzetü, alapvetően homokbuckás területen a talajtakaró vékony, a fölső két mintát mindig a legfölső, szemcsevizsgálatokra mintázott mélységközböl (többnyire a 0-0,5 m tartományból) gyüjtöttük be. A mintaterületet, a fúrások helyét és a földtani szempontból elkülönített vegetáció típusokat az 2. ábrán mutatjuk be.

A mintaterület geokémiai viszonyait az 1998-99-es felvétel 88 fúrásának 429 mintája alapján mutatjuk be.

\section{Mintaelőkészítés, analitika}

A mintákat az eredeti zacskóikban szárítottuk be légszárazra. A nyomelemvizsgálatra szánt mintákat $63 \mu$ lyukátmérőjü szitán leszitáltuk. Az áthullott anyagot golyósmalom tégelyében átforgatva homogenizáltuk.

A nyomelemeket az első mintasorban Lakanen-Erviö módszerrel tárták föl, a második sorozatot pedig salétromsavval. Ennek következtében a két sorozat összevetéséből nem tudtunk következtetni az eltelt idő alatti geokémiai változásokra, pedig az eredeti célunk ez volt.

A nyomelemeket ICP-AES módszerrel határozták meg (Jobin Yvon 70 típusú szimultán szekvens induktív csatolású plazma emissziós spektrométer).

\section{Adatfeldolgozás}

Az üledékföldtani értékelésekben szerepel minden szemcsevizsgálat a mérés jellegéből adódó szokásos hibák elöírásos korrigálása után.

A nyomelem-tartalmak értékelésében szerepel minden olyan tömény savas nyomelemzés, amihez van szedimentvizsgálat (a két fölső mintát ugyanahhoz a szemcsevizsgálathoz rendeltük). Az adatállományt a terepi jegyzőkönyvek és a szedimentvizsgálatok alapján a Típusos képződmények fejezetben leírt csoportokra bontottuk; a csoportok alapvető jellemzőit egydimenziós statisztikai próbákkal határoztuk meg.

Először azt vizsgáltuk meg, hogy az egyes képződményekben az egyes komponensek eloszlásai szignifikánsan eltérnek-e az egyensúlyi helyzetekben 
várható (FüGEDI, TOLMÁCS, BARCZIKAINÉ SZEILER, 2015) normál, illetve lognormál eloszlástól. Figyelembe véve, hogy egy-egy mintából a komponensek koncentrációját csak akkor ismerhetjük meg, ha azok meghaladják a kimutatási határt, általános tanulságként megállapítható, hogy gyakorlatilag valamennyi vizsgált komponens eloszlása minden képződményben szabálytalanul aszimmetrikus, tehát adataink numerikus feldolgozására a parametrikus statisztikák nem alkalmasak. Ezt a közismert következtetést (STEINER 1990) újólag alátámasztja, hogy bár kísérleteztünk többdimenziós eljárásokkal (főkomponens- és diszkriminancia-analízissel) is, de ezek a Kendall-féle $\tau$-ra alapozó statisztikai program hiányában nem adtak értelmezhető eredményt.

$\mathrm{Az}$ egydimenziós próbák közül a várható érték becslésének a mediánt, a változékonyság mérőszámának az interkvartilis félterjedelmet fogadtuk el. Az egyes változók kapcsolatait a Kendall-féle rangkorrelációval jellemeztük.

\section{A szedimentológiai vizsgálatok értékelése}

1. Az egyes üledékek összetétele a kőzetlisztes agyagtól a finomhomokos durvahomokig változó; a durvahomok $(>0,5 \mathrm{~mm})$ tömege csak három fúrás (ezek közül kettő szomszédos) mindössze négy mintájában lépi túl az $5 \%$-ot. Ezek olyan, mai vagy egykori felszínek, amelyekröl a szél kifújta a finomabb szemcséket. Külön csoportként kell kezelnünk a semlyékekben, tavacskákban kialakult, erősen karbonátos üledékeket, amiket a terepi jegyzőkönyv „mésziszap” néven említ.

2. Megfigyeléseink szerint karbonátelemzésekkel kimutatott „kalcit”- és „dolomit”-tartalmak valójában nem ásványtanilag közel sztöchiometrikus összetételü kalcit-, illetve dolomit ásványokat jelölnek, hanem egyszerüen a könnyebben, illetve nehezebben oldható karbonátásványokat (FÜGEDI, et al., 2006; FÜGEDI, et al., 2008a). A gyorsan oldódó karbonáttartalmat (kalcit) Scheiblermódszerrel mérték (10-15 perces mérés), a lassan oldódót (dolomit) az ún. áztatásos eljárással (24 órás mérés). Minél kevésbé diagenizált valamely karbonát, annál lazább a Scheibler-módszerü és a kalcium- és magnézium-elemzésekből számolható kalcit-, illetve dolomittartalom kapcsolata. Egy valós üledékképződési környezetben a Ca- és Mg-karbonát mellett más sóásványok (pl. gipsz, sziksók) is lehetnek, és ezek annál könnyebben, gyorsabban távoznak az oldatba, minél nagyobb az adott szemcse fajlagos felülete. Az oldódás üteme fordított arányban áll az érintett szemcse diagenizáltságával, mivel az összepréselődött szemcsék hozzáférhető reakciófelülete jelentősen kisebb.

A karbonátásványok oldékonyságát a diagenizáltság, s így a fajlagos felület mellett további tényezők is befolyásolják:

- a kalciumot, illetve a magnéziumot helyettesítö kationok ( $\mathrm{Sr}, \mathrm{Ba}$ stb.) mennyisége,

- az egyszerüség kedvéért mésziszapnak nevezett kiválásokban a karbonát mellett előforduló egyéb anionok (szulfát, foszfát, hidrogénkarbonát stb.), a mész és dolomit mellett előforduló egyéb ásványok (gipsz, sziksó stb.). 
A savoldható ionok és a Scheibler-módszerü karbonáttartalmak korrelációja a Bugaci-mintaterületen is elég gyenge (3. ábra és 1. táblázat)

\section{1. táblázat}

A Scheibler-módszerü karbonáttartalmak és a savoldható Ca-, illetve Mg-tartalom korrelációs kapcsolatai (Kendall-féle $\tau$ )

\begin{tabular}{|l|l|l|l|}
\hline ion/ásvány (1) & „kalcit” (2) & ,dolomit” (3) & Cc+Dol \\
\hline $\mathrm{Ca}$ & 0,276 & 0,174 & 0,248 \\
\hline $\mathrm{Mg}$ & 0,279 & 0,215 & 0,251 \\
\hline $\mathrm{Ca}+\mathrm{Mg}$ & 0,279 & 0,182 & 0,250 \\
\hline $\mathrm{Na}$ & 0,066 & 0,102 & 0,105 \\
\hline
\end{tabular}

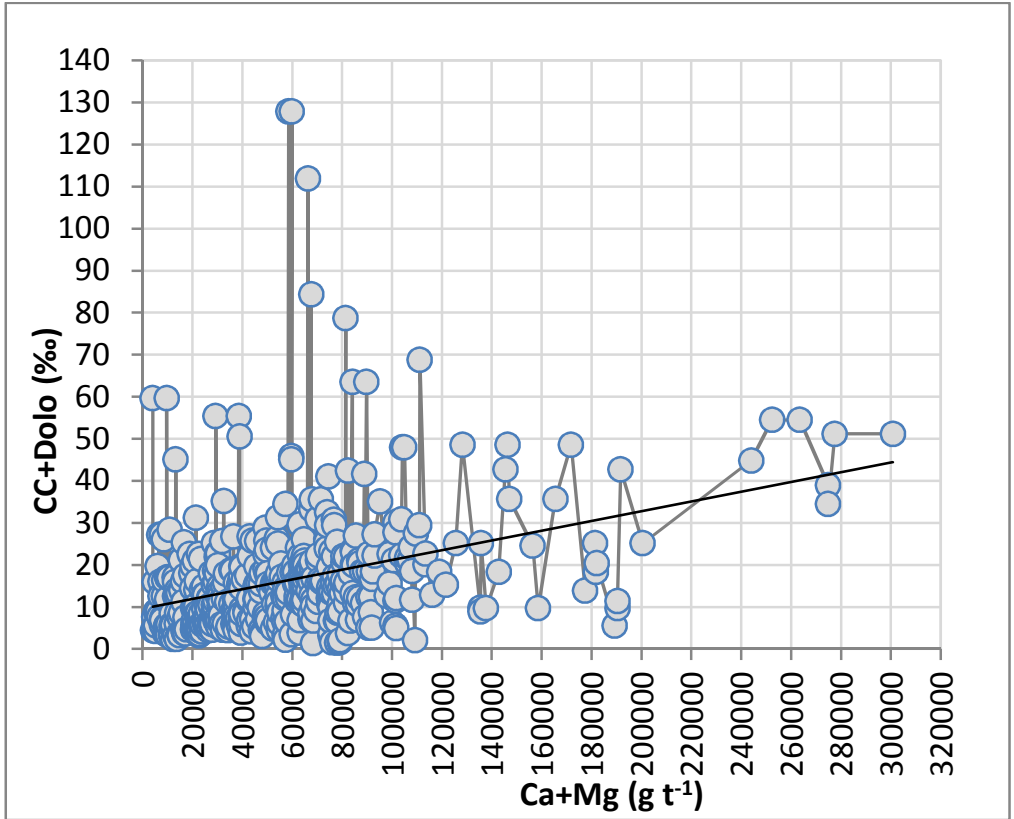

\section{3. ábra}

A savoldható ionok (x-tengely) és a Scheibler-féle karbonáttartalom (y-tengely) lineáris regressziója a trendvonallal

A savoldható ionok és a Scheibler-féle karbonáttartalom kapcsolatát (3. ábra) áttekintve leginkább az ötlik szembe, hogy a trend szerint $8 \%$ „karbonát”ásvány akkor is várható, ha a Ca- és a Mg-tartalom is a nullához közelít. A két adatsor ily erőteljes különbözősége annak következménye, hogy a mért kation- és aniontartalmat más-más tényezők befolyásolják. A „karbonát” mennyiségét a sóásványok beoldódása növeli meg, viszont valamennyi $\mathrm{Ca}^{++}$és $\mathrm{Mg}^{++}$az agyagásványok felületéről is beoldódik. Előbbi tényezőt jól jelzi, hogy a 
Scheibler-féle karbonát ásványok koncentrációival a táblázat alsó sorában szereplő Na mennyisége is pozitívan korrelál.

A kapcsolat számszerü értékeléséhez meg kell vizsgálnunk, mennyire „húzzák el" a regressziós egyenest a nagy koncentrációk. A vizsgált komponensek eloszlása ugyanis - amint ezt a 4. ábrán bemutatjuk - több maximumos. Másként fogalmazva: mivel a savoldható ionok és a Scheibler-féle karbonáttartalom kapcsolatát jellemző regressziós egyenes meredeksége nem független a néhány, az átlagot jóval meghaladó értéktől, ezért lényeges látni, hogy az egyenes meredekségét hány és mekkora koncentráció befolyásolja, tolja el? A kiugró értékek hatására ugyanis hamis - pontosabban a kiugró értékektől befolyásolt - kép jelenik meg az adatokkal sürün jellemzett koncentráció-tartományban is.

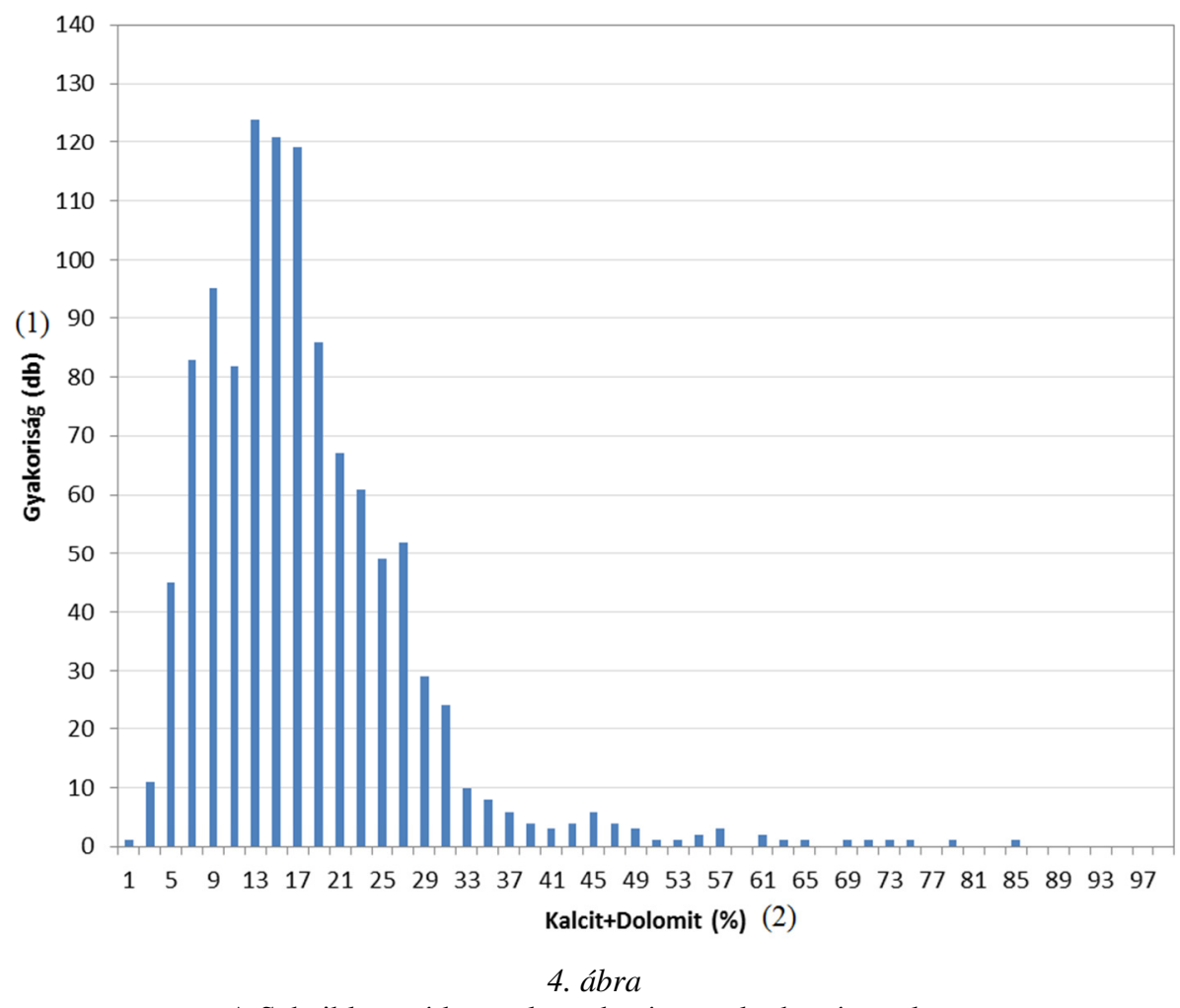

A Scheibler-módszerrel meghatározott karbonáttartalom $(\mathrm{Cc}+\mathrm{Dol}, \%)$ eloszlása $(\mathrm{N}=1090)$

Az eloszlást a 41\%-nál kirajzolódó gyakorisági minimumnál két részre bontva megállapíthatjuk, hogy:

1. a nagy koncentrációk tartományában - amiben kevés az adat és a 41\%-os minimumtól jobbra található - a savoldható alkáliföldfémek és a Scheibler-féle karbonáttartalom kapcsolata megszűnik; 
2. a $\mathrm{Ca}+\mathrm{Mg}=0$ hipotetikus esetben a Scheibler-féle karbonáttartalom várható értéke 9\%.

Nagyon fontos leszögeznünk, hogy ez nem azt jelenti, hogy legalább $9 \%$ savoldható ásvány minden mintában, minden földtani képződményben van: a kvantitatív becsléshez a Scheibler-féle karbonáttartalmakat nem a $\mathrm{Ca}^{++}$és $\mathrm{Mg}^{++}$ ionok mennyiségével, hanem az azokból számolt karbonáttartalmak összegével kellene összevetni. Ám az így számolt eredmény is félrevezető lenne:

- egyrészt a föntebb említetteknek megfelelően az elemzésekben megjelenő Ca- és Mg-ionok nem csak karbonát ásványokból oldódnak be;

- másrészt a föntebb kimutatott kapcsolatok a nagy mintaszámnak köszönhetően nagyon szignifikánsak ugyan, de egyúttal nagyon gyengék is: 0,2-es korrelációs együttható a teljes változékonyságnak mindössze 4(!)\%-át, 0,25-os együttható alig 6(!)\%-át magyarázza. Ilyen kedvezőtlen $\mathrm{jel} /$ zaj viszonyok mellett a becslés csak pontatlan lehet.

\section{Elemarányok és földtani jelentőségük}

\section{$\underline{\mathrm{Ca} / \mathrm{Sr}}$}

A hasonló helyzetü Fülöpházai-mintaterületen kimutattuk (FüGEDI, et al., 2006), hogy a Ca és a Sr korrelációja a viszonylag kis koncentrációk (a kapilláris vízböl kicsapódó karbonátásványok) tartományában rendkívül szoros, a nagyobb karbonáttartalmú tavi mésziszapokban viszont erőteljesen leromlik: a Sr relatíve felhalmozódik, ahogy az élő szervezetek kivonják e képződményekből a kalciumot. Mivel a kalcium az, aminek eloszlását a biogén aktivitás eltorzítja, a két képződménytípus a legkönnyebben a Sr-tartalmak alapján válogatható külön.

Bugaci tapasztalataink ezt a modellt mindenben alátámasztják. A két elem kapcsolata (5. ábra) a kis koncentrációk tartományában ehelyütt is rendkívül szoros, a nagy értékeknél pedig fellazul, mert a minták nagy többségében a $\mathrm{Sr}$ feldúsul.

A kevés stronciumot tartalmazó mintákat leválogatva rendkívül szoros regressziót kapunk; Bugacon a felszín alatti mészakkumuláció és a tavi mésziszapok geokémiai határa valahol a $\mathrm{Sr}=110$ és a $\mathrm{Sr}=200 \mathrm{~g} \mathrm{t}^{-1}$ koncentráció között, $\mathrm{Sr}=150 \mathrm{~g} \mathrm{t}^{-1}$ körül lehet. 


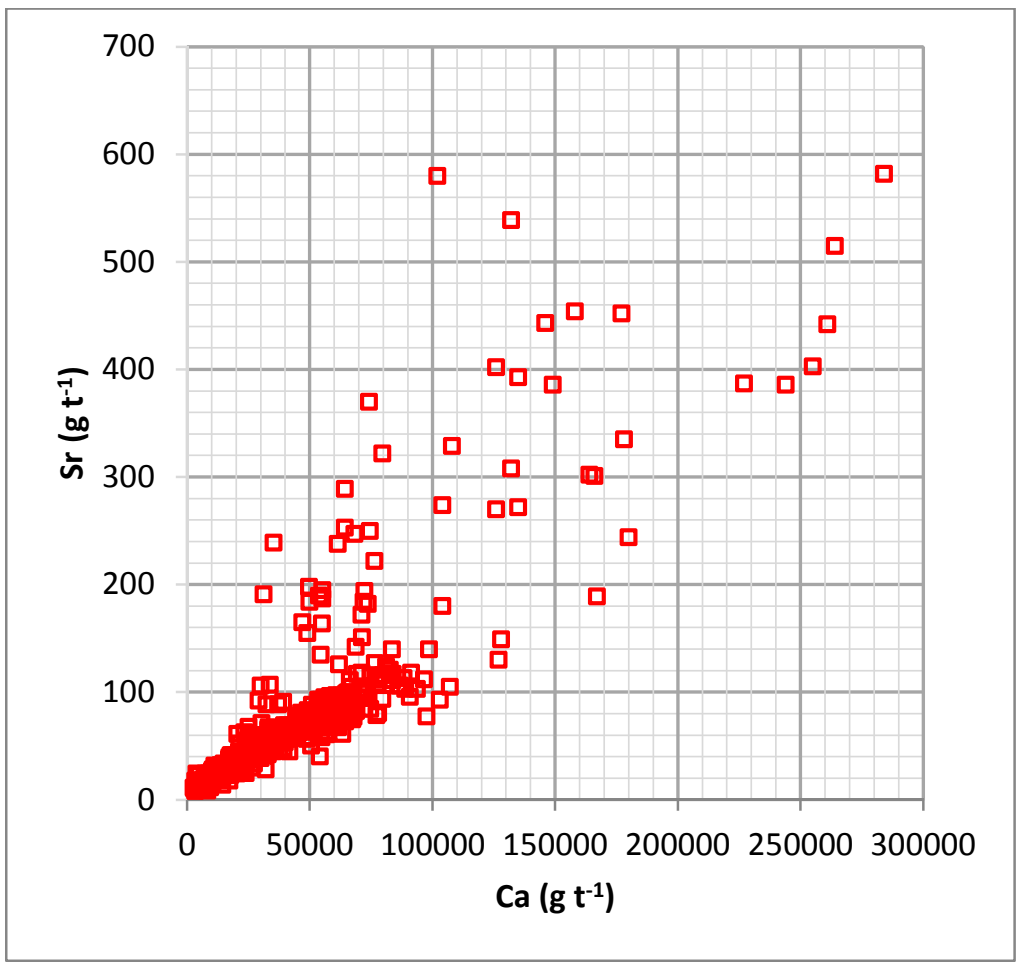

\section{5. ábra}

A Ca és a Sr kapcsolata a bugaci mintaterületen $(\mathrm{N}=430)$

\section{$\underline{\mathrm{Cr} / \mathrm{Mo}}$}

A króm és molibdén geokémiailag antagonista; a természetben együttes felhalmozódásukra nem ismerünk adatot. Éppen ezért már hosszabb ideje nyugtalanított minket, hogy nagyobb koncentrációik alföldi mintáinkban rendszeresen együtt jelentek meg — mostani adatsorunk előtt azonban ezek annyira szórványosak voltak, hogy e sajátos jelenség okainak tisztázására nem volt lehetőségünk.

A molibdén koncentrációját ezúttal 35 mintából sikerült meghatározni sajnos, kimutatási határa $\left(1 \mathrm{~g} \mathrm{t}^{-1}\right)$ a háttér értéktartomány legtetején, illetve afölött van. Mivel a Cr e mintákban szintén megjelenik, valószínüsítettük, hogy e két elem szoros korrelációja a minták valamiféle szennyezésének eredménye:

- Pearson (r) - 0,886 (> 99\%)

- Spearman $(\rho)-0,583(>99 \%)$

- Kendall $(\tau)-0,458(>99 \%)$

Ebben az esetben minden, a kimutatási határ fölötti Mo-koncentráció szennyezés, tehát mintavételi hiba következménye; a háttér értéktartomány $1 \mathrm{mg} \mathrm{kg}^{-1}$ alatt van. 
A jelen munkánkkal párhuzamosan értékelt Fülöpházai-mintaterületen (FÜGEDI,et al., 2006) kimutattuk, e két elem „különös házassága” annak köszönhető, hogy a törmelékes üledékekben szép számmal előforduló kvarcszemcsék a csigafúró fejét belekoptatják a mintába. Szükségképpen se a pozitív molibdén-értékeknek, se a $80 \mathrm{~g} \mathrm{t}^{-1}$ fölötti króm-koncentrációknak semmiféle földtani jelentősége nincs:

- a Mo tényleges mennyiségéröl csak azt tudjuk, hogy a kimutatási határnál kevesebb;

- a Cr megadott koncentrációi fölső becslésekként kezelendők;

- a mintákat szennyező fémforgácsok más elemek koncentrációit a kimutathatónál kisebb mértékben befolyásolják.

E folyamatot és annak következményeit külön publikációban kívánjuk kvantitatívan elemezni.
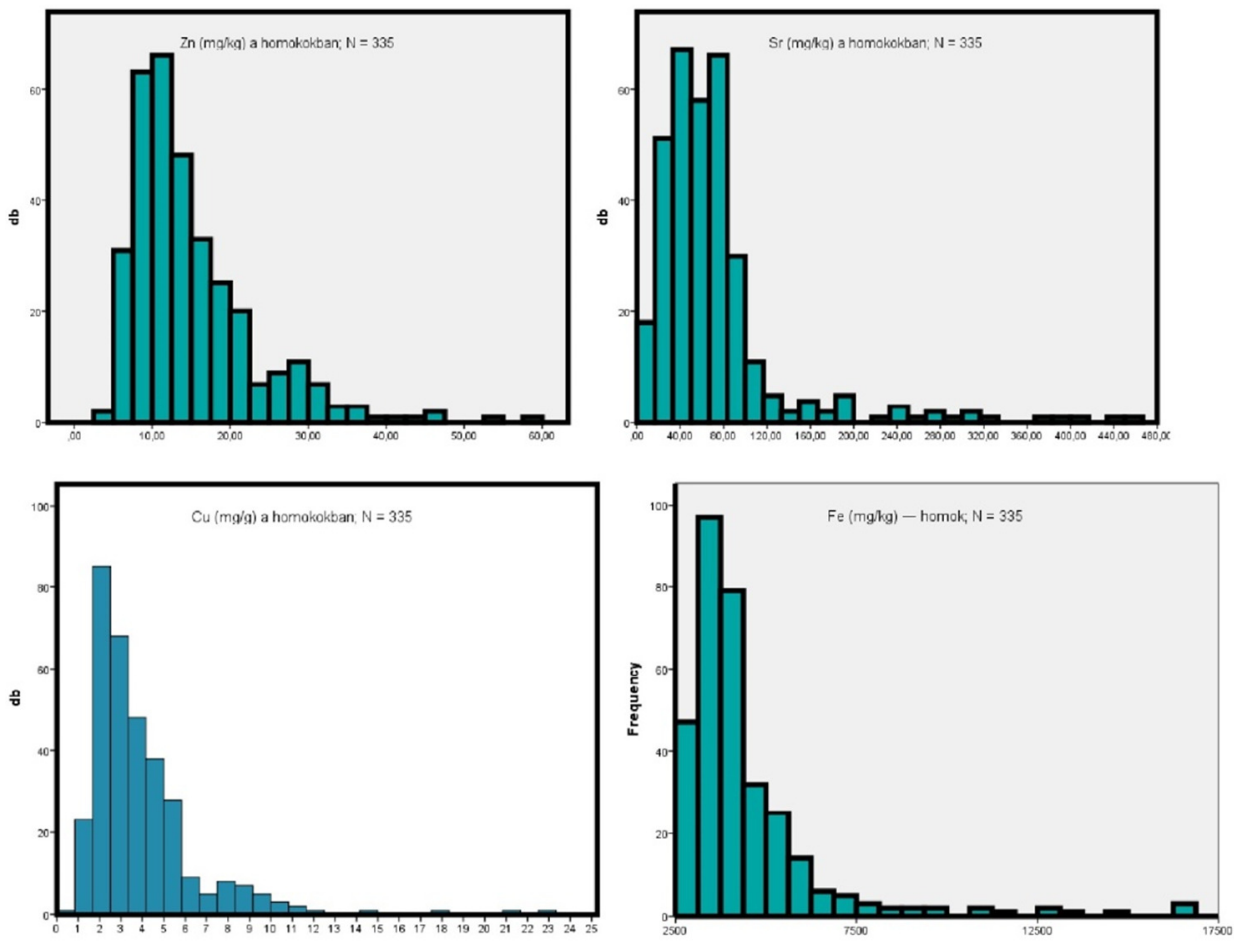

6. ábra

Aszimmetrikus elem-eloszlások a bugaci mintaterület mintáiban

\section{Típusos képződmények}

A várható értékek, illetve változékonyságok becslései - interkvartilis félterjedelmek, 2. táblázat - jellemzően közel azonosak (gyakorta utóbbiak 
nagyobbak). Ez és az eloszlások szabálytalanul aszimmetrikus jellege (viszonylag sok kiugró értékkel, gyakran másodlagos gyakorisági maximummal - 6. ábra) befejezetlen migrációs folyamatokra utal: a jelenleg is intenzív oldás-kicsapódás dinamikus egyensúlyi állapotai tolódnak el fölfelé, illetve lefelé a talajvíztükörrel és a laposok gyakorta függő vizeivel.

\section{2. táblázat}

Üledéktípusok statisztikai paraméterei $\left(\mathrm{g} \mathrm{t}^{-1}\right)$

\begin{tabular}{|c|c|c|c|c|c|c|c|c|c|c|}
\hline \multirow[b]{2}{*}{$\begin{array}{l}\text { elem } \\
(6)\end{array}$} & \multicolumn{2}{|c|}{ Mésziszap (1) } & \multicolumn{2}{|c|}{$\begin{array}{c}\text { Agyagos } \\
\text { kőzetliszt (2) }\end{array}$} & \multicolumn{2}{|c|}{ Futóhomok (3) } & \multicolumn{2}{|c|}{$\begin{array}{l}\text { Homokos lösz, } \\
\text { löszös homok } \\
\text { (4) }\end{array}$} & \multicolumn{2}{|c|}{ Lösz (5) } \\
\hline & \begin{tabular}{|l|}
$\begin{array}{l}\text { medián } \\
(7)\end{array}$ \\
\end{tabular} & $\begin{array}{l}8) \text { int. } \\
\text { félterj. }\end{array}$ & $\begin{array}{l}\text { medián } \\
(7)\end{array}$ & $\begin{array}{l}\text { (8) int. } \\
\text { félterj. }\end{array}$ & \begin{tabular}{|l|} 
medián \\
$(7)$
\end{tabular} & $\begin{array}{l}\text { (8) int. } \\
\text { félterj. }\end{array}$ & $\begin{array}{l}\text { medián } \\
(7)\end{array}$ & $\begin{array}{l}\text { (8) int. } \\
\text { félterj. }\end{array}$ & $\begin{array}{l}\text { medián } \\
(7)\end{array}$ & $\begin{array}{l}\text { (8) int. } \\
\text { félterj. }\end{array}$ \\
\hline $\mathrm{V}$ & 6,2 & 3,4 & \begin{tabular}{|l|l}
5,6 & \\
\end{tabular} & 3,8 & 4,6 & 1,8 & 9,2 & 9,4 & 14 & 11 \\
\hline $\mathrm{P}$ & 445 & 211 & 250 & 410 & 195 & 110 & 230 & 175 & 360 & 360 \\
\hline $\mathrm{Pb}$ & 8,4 & 8,3 & 8,1 & 3,8 & 8,2 & 7 & 8,6 & 7,4 & 4,5 & 7,9 \\
\hline $\mathrm{Co}$ & $<2$ & - & $<2$ & - & $<2$ & - & $<2$ & - & 3,3 & 4,7 \\
\hline$S$ & 160 & 335 & $<50$ & - & $<50$ & - & $<50$ & - & $<50$ & - \\
\hline $\mathbf{N a}$ & 400 & 300 & 320 & 210 & 260 & 200 & 260 & 270 & 460 & 460 \\
\hline $\mathrm{Li}$ & 5,9 & 2,6 & 4,2 & 3,2 & 4,2 & 1,9 & 6,2 & 5,7 & 9,8 & 9,6 \\
\hline K & 580 & 440 & 690 & 500 & 560 & 290 & 565 & 490 & 960 & 540 \\
\hline $\mathrm{Cr}$ & 4,3 & 4,2 & 3,9 & 8,2 & 4 & 3,1 & 6,4 & 8 & 13 & 12 \\
\hline $\mathrm{Zn}$ & 15,8 & 8,3 & 12 & 13 & 13 & 9 & 16 & 13 & 24 & 21 \\
\hline $\mathrm{Ni}$ & 5,5 & 3 & 3 & 2,6 & 4,9 & 2,6 & 8,5 & 4,7 & 13 & 12 \\
\hline $\mathrm{Ba}$ & 57 & 42 & 22 & 16 & 18 & 10 & 28 & 19 & 35 & 25 \\
\hline $\mathrm{Mn}$ & 250 & 120 & 120 & 85 & 122 & 56 & 170 & 110 & 180 & 200 \\
\hline $\mathrm{Cu}$ & 5,1 & 3,6 & 3,4 & 2,7 & 3,1 & 2,2 & 4,3 & 4,7 & 7,2 & 8,3 \\
\hline $\mathrm{Ti}$ & 34 & 18 & 39 & 48 & 38 & 17 & 63 & 50 & 98 & 101 \\
\hline $\mathrm{Sr}$ & 250 & 202 & 81 & 47 & 54 & 43 & 78 & 47 & 62 & 59 \\
\hline $\mathrm{Ca}$ & 98560 & 93650 & 60400 & 15400 & 31000 & 35260 & 57200 & 29600 & 48200 & 43200 \\
\hline $\mathrm{Fe}$ & 5050 & 2660 & 3930 & 2350 & 3800 & 1350 & 5640 & 6560 & 9950 & 9300 \\
\hline $\mathrm{Mg}$ & 16600 & 9200 & 11900 & 7100 & 4800 & 5700 & 9500 & 8900 & 10000 & 16400 \\
\hline $\mathrm{Al}$ & 2980 & 2350 & 2500 & 2240 & 2600 & 1200 & 4000 & 4400 & 6500 & 4900 \\
\hline
\end{tabular}

A mintaterületen az alábbi üledéktípusokat különböztettük meg:

1. Tavi üledékek: 1.1. mésziszap (51 minta),

1.2. agyagos finom közetliszt (10 minta).

2. Eolikus üledékek: 2.1. futóhomok (301 minta),

2.2. löszös homok - homokos lösz (24 minta),

2.3. lösz (36 minta). 
A mésziszapok (a többi képződményhez képest) kiugróan nagy kéntartalma megerősíti azt a korábbi feltételezésünket, hogy mintaterületünkön az összes karbonáttartalom egy (kis) része szulfát. Jól mutatja ezt a kén, illetve az összes karbonáttartalom és a nátrium-kálium elempár negatív korrelációja a mésziszapokban: a szulfátos közegből az alkáli fémek kimosódnak.

A futóhomok szemcséinek elsöprő többsége a $0,06-0,5 \mathrm{~mm}$ tartományba esik; eloszlásuk egymaximumos. Modális összetétele:

$-<0,06 \mathrm{~mm}-8 \%$

$\bullet 0,06-0,1 \mathrm{~mm}-10 \%$

- $0,1-0,2 \mathrm{~mm}-51 \%$

- $>0,2 \mathrm{~mm}-31 \%$

Az üledékek szemcseméretétől függetlenül felhalmozódó Ca és $\mathrm{Sr}$ (valamint a felszín közelében nagyon kevéssé mozgékony ólom) kivételével az eolikus üledékek közül minden vizsgált elemből a homokokban van a legkevesebb; az elemtartalmak az agyagfrakció arányával nőnek.

\section{Nyomelemháztartás}

Az egyes BFK-szintek várható értékeit (3a. és 3b. táblázat) összehasonlítva néhány érdekes törvényszerüségre figyelhetünk fel:

1. A biogén elemek (foszfor, kén) koncentrációinak a talaj A szintje alatt, a rétegsor legalján egy másik, az A szintben megfigyelhetőnél kissé erőteljesebb maximuma is megjelenik. Lehet, hogy ez eltemetett talajszintet jelez;

2. Ugyancsak a rétegsor alján több más, egymással geokémiailag egyáltalán nem rokonítható elemnek ( $\mathrm{Fe}, \mathrm{Mn}, \mathrm{V}, \mathrm{Cr}, \mathrm{Ni}$, illetve $\mathrm{K}$ és $\mathrm{Li}$ ) is koncentrációmaximuma van. Ezeket az elemeket valószínüleg a karbonátok felhalmozódása szorítja ki a rétegsor magasabb részeiböl;

3. Az alkáli földfémek közül a kalcium dúsulásának maximuma a magnéziumé fölött van. Mivel a kalcium kevésbé oldékony, mint a magnézium, a leszálló csapadékvízből hamarabb válik ki;

4. A legtöbb elem vertikális megoszlása kimondottan egyenletes. Ez arra utal, hogy a földtani értelemben fiatal, dinamikus felszín alatt, illetve az antropogén beavatkozásoktól is erősen változó talajvíztükör fölött az egyensúlyi állapot és a rá jellemző zonalitás még nem alakult ki.

A legfontosabb esszenciális mikroelemek (réz, cink) várható értéke egyetlen vizsgált képződményben, egyetlen vizsgált szintben sem éri el a növények számára minimálisan szükséges koncentrációt $\left(\mathrm{Cu}: 8 \mathrm{~g} \mathrm{t}^{-1}, \mathrm{Zn}: 40 \mathrm{~g} \mathrm{t}^{-1}-\right.$ SZABÓ, et al., 1987). A terület - miként a középső geokémiai nagytáj homokjai általában (FÜGEDI, et al., 2008a.) - közepesen rézhiányos és erősen cinkhiányos. 
3a. táblázat

ICP-vel vizsgált elemek várható értékei (medián, $\mathrm{g} \mathrm{t}^{-1}$ ) a BFK-szintekben

\begin{tabular}{|l|l|l|l|l|l|l|l|l|l|l|l|}
\hline Medián & $\mathrm{V}$ & $\mathrm{Mo}$ & $\mathrm{P}$ & $\mathrm{Pb}$ & $\mathrm{Co}$ & $\mathrm{Cd}$ & $\mathrm{S}$ & $\mathrm{Na}$ & $\mathrm{Li}$ & $\mathrm{K}$ & $\mathrm{As}$ \\
\hline A1 & 4,5 & $<0,2$ & 269 & 9,8 & $<0,5$ & $<0,2$ & 18,7 & 258 & 4,3 & 592 & $<2$ \\
\hline A2 & 4,4 & $<0,2$ & 222 & 9,1 & $<0,5$ & $<0,2$ & 4,43 & 279 & 4,1 & 578 & $<2$ \\
\hline B & 4,8 & $<0,2$ & 152 & 7,3 & $<0,5$ & $<0,2$ & 3 & 294 & 4,3 & 534 & $<2$ \\
\hline C & 5,1 & $<0,2$ & 194 & 7,4 & $<0,5$ & $<0,2$ & 3 & 276 & 4,6 & 544 & $<2$ \\
\hline D & 9,1 & $<0,2$ & 276 & 8,2 & $<0,5$ & $<0,2$ & 25 & 281 & 6,3 & 704 & $<2$ \\
\hline
\end{tabular}

3b. táblázat

ICP-vel vizsgált elemek várható értékei (medián, $\mathrm{g} \mathrm{t}^{-1}$ ) a BFK-szintekben

\begin{tabular}{|l|l|l|l|l|l|l|l|l|l|l|l|l|}
\hline Medián & $\mathrm{Cr}$ & $\mathrm{Zn}$ & $\mathrm{Ni}$ & $\mathrm{Ba}$ & $\mathrm{Mn}$ & $\mathrm{Cu}$ & $\mathrm{Ti}$ & $\mathrm{Sr}$ & $\mathrm{Ca}$ & $\mathrm{Fe}$ & $\mathrm{Mg}$ & $\mathrm{Al}$ \\
\hline A1 & 4,0 & 17 & 5 & 22 & 149 & 4,8 & 34,2 & 42 & 24200 & 3850 & 3705 & 2640 \\
\hline A2 & 3,6 & 14 & 4,9 & 21,2 & 138 & 3,6 & 34,4 & 46,1 & 24700 & 3840 & 3984 & 2638 \\
\hline B & 4,0 & 10 & 4,7 & 18,6 & 116 & 2,5 & 38,5 & 75,4 & 52150 & 3800 & 6555 & 2541 \\
\hline C & 4,2 & 11 & 5,7 & 19,2 & 112 & 2,8 & 50 & 76,7 & 53350 & 3900 & 9280 & 2665 \\
\hline D & 8,8 & 21 & 9,5 & 26 & 149 & 5,1 & 82,3 & 68,9 & 51300 & 6880 & 10250 & 4670 \\
\hline
\end{tabular}

\section{Következtetések és összefoglalás}

A majd' $50 \mathrm{~km}^{2}$-es Bugaci-mintaterületen négy sekélyfúrásos vizsgálati programot végeztünk el. A vizsgálati eredmények közül az 1998-99-es mintázás nyomelem-adatainak eleddig hiányzó értelmezését adjuk közre.

A buckákon futóhomok, a laposokon agyagos-finomkőzetlisztes üledék található; ez utóbbi jelentős része karbonátiszap. Bár a laposok gyakorlatilag lefolyástalanok, a buckák-laposok helyzete nem állandó, így a rájuk jellemző üledékek is keverednek. A laposok alatti talajvízben és a laposok felszínén az időszakos tavakban a bepárlódás miatt megnő az oldott ion (só-) tartalom. A szedimentológiai és nyomelem-vizsgálatok alapján két sajátos környezetet érdemes kiemelni: a mai/archív felszíneket, amelyeken több a durvaszemcsés homok, valamint a semlyékek karbonátos, finomszemcsés üledékeit.

A felszínhez közel - a mészakkumuláció komponensei, azaz a $\mathrm{Ca}, \mathrm{Mg}, \mathrm{Sr}$, $\mathrm{Ba}, \mathrm{CO}_{3}{ }^{2-}, \mathrm{SO}_{4}{ }^{2-}, \mathrm{PO}_{4}{ }^{3-}$ (FÜGEDI et al., 2006) kivételével - az eolikus és a tavi üledékekben is minden vizsgált elemböl jóval kevesebb van a Magyarországon általában szokásosnál. Ebben az értelemben a Bugaci-mintaterület jól reprezentálja Magyarország középső geokémiai nagytáját. Az ezen a nagytájon másutt megfigyelt törvényszerüségekkel teljes összhangban a karbonátok felhalmozódása közben az 
üledékekből valamennyi egyéb ion kimosódik: minél jobban oldódik, annál intenzívebben.

A Scheibler-módszerü, illetve áztatásos karbonáttartalmak csak nagyon lazán korrelálnak a Ca és $\mathrm{Mg}$ savoldható koncentrációival, mivel a kioldásos elemzéseket erősen befolyásolják egyéb tényezők (más sóásványok, az üledék diagenizáltsága). $\mathrm{Az}$ együtt elöforduló, kiugróan nagy $\mathrm{Cr}$ - és Mo-tartalmakat automatikusan szennyezésnek kell tekinteni.

A tavi mésziszapokban a $\mathrm{Ca} / \mathrm{Sr}$ arányt biogén folyamatok határozzák meg; ugyanezen iszapok kiugró S-tartalma bepárlódás eredménye. A mészakkumuláció elemcsoportja $\left(\mathrm{Ca}, \mathrm{Mg}, \mathrm{Sr}, \mathrm{Ba}, \mathrm{CO}_{3}{ }^{2-}, \mathrm{SO}_{4}{ }^{2-}, \mathrm{PO}_{4}{ }^{3-}\right)$ kivételével minden vizsgált elemből a Magyarország legnagyobb részén szokásosnál jóval kevesebb fordul elő. A tavi mésziszapok a Sr-tartalmak alapján megbízhatóan elkülöníthetők a mélyebb helyzetben kialakult mészakkumulációs szintektől.

A mintaterület talajai (föleg a homoktalajok) közepesen rézhiányosak és erősen cinkhiányosak.

Kulcsszavak: Bugac, nyomelemek, karbonátok, elemkorreláció, nyomelemháztartás

\section{Irodalom}

BARTHA A., FÜGEDI U., KUTI L., 1991. Determination of mobile nutrient microelements in younger loose sedimentary rocks. XXVII. Colloquium Spectroscopicum Internationale (poster session), Bergen, Norway

FÜGEDI U., SZURKOS G., VERMES J., 2005. Éghajlatváltozások geokémiai hatásai Magyarország középső és keleti részén. MÁFI Évi Jel. 2004-ről. 65-71.

FÜGedi U., Pocsai T., KuTI L., Horváth I., 2006. A talajok meszesedésének földtani okai Közép-Magyarországon. „Újabb eredmények a szikesedés földtani körülményeiről” előadóülés, MTA TAKI, 2006. nov. 8. http://www.taki.iif.hu/7fuub.pdf

FÜGEDI U., POCSAI T., KUTI L., HoRVÁth I., VATAI J., 2008a. A mészfelhalmozódás földtani okai Közép-Magyarország talajaiban. Agrokémia és Talajtan 57. (2) 239-260.

FÜGEDI U., SZURKOS G., VERMES J., KUTI L., 2008b. Geochemical fingerprints of climatic changes in Central and Eastern Hungary. Analele Ştiinţifice ale Universităţii “Al. I. Cuza” Iaşi. Geologie LI. 45-56. http://geochemistry.uaic.ro/auig/art\%20arch/pag.\%204556\%20(lucrarea\%2004_2005).pdf

FÜGEDI U., TOLMÁCS D., BARCZIKAINÉ SZEILER R., 2015. Toxikus és esszenciális mikroelemek háttér értéktartományai. In Csicsek G., Kiss I. (szerk): XI. Kárpát-medencei Környezettudományi Konferencia tanulmánykötete, Pécs, 2015. május 6., 27-45. 
KerÉK B., Kuti L., VATAI J., 2002. Az Északkelet-Alföld felszíni felszínközeli képződményeinek és a bennük mozgó talajvíznek az agrogeológiai környezetföldtani jellemzése. Acta Geographica ac Geologica et Meteorologica Debrecina, Tom. XXXV. 103-116.

KERÉK B., 2003. A talaj-alapközet-talajvíz rendszer agrogeológiai vizsgálata a Bugaci-mintaterületen. Doktori (PhD) értekezés. Kézirat, Debreceni Egyetem, Ásvány- és Földtani tanszék. http://ganymedes.lib.unideb.hu:8080/dea/bitstream/2437/78276/1/tz_eredeti21 51.pdf

KUTI L., TUlLner T., 1994. Distribution of nutrient elements in the soil of the Szarvas area, Hungary. ITC Journal, 1994. (1) 40-43

KUTI L., ZENTAY T., KERÉK B., 2002. A Bugaci- és Fülöpi-mintaterületek felszínközeli üledékeinek kalcium-karbonát tartalma. MÁFI Évi Jelentés 1997-1998-ról. 107-117.

KUTI L. (szerk.), 2009. Agrogeológia. Dura Stúdió, Budapest.

MolNÁr B., 1980. Hiperszalin tavi dolomitképződés a Duna-Tisza közén. Földtani Közlöny. 110. 45-64.

MOLNÁR B., BOTZ R., 1996. Geochemistry and stable isotope radio of modern carbonates in natron lakes of the Danube-Tisza interfluve, Hungary. Acta Geol. Hung. 39. (2) 153-174.

MOLNÁR B., SCHNEIDER-LÜPKES, U., 2001. Az időszakos Péteri-tó (Kiskunsági Nemzeti Park) keletkezése és üledékképződése. Földtani Közlöny. 131. 475-497.

MOLNÁr B., SzÓNOKY M. \& KovÁCS S., 1981. Recens hiperszalin dolomitok diagenetikus és litifikációs folyamatai a Duna-Tisza közén. Földtani Közlöny. 111. 119-144.

STEINER F., 1990. A geostatisztika alapjai. Tankönyvkiadó, Budapest. 9631828190

SZAbó S. A., Regiusné MöCsénYi Á., GyöRI D. , SZEnTmihályi S., 1987. Mikroelemek a mezőgazdaságban. I. Esszenciális mikroelemek. Mezőgazdasági Kiadó, Budapest.

TóTH T., SZENDREI G., 2006. A sókivirágzások elterjedésének és képződésének összefüggése a környezeti, ezen belül talajtani tényezőkkel. In: A magyarországi szikes talajok felszíni sóásványai. (Szerk.: SzENDREI G. \& TóтH T.) 79-89. Topographia Mineralogica Hungariae. IX. Hermann Ottó Múzeum. Miskolc.

UjHÁZY K., GÁBRIS G., FrECHEN, M., 2003. Ages of periods of sand movement in Hungary determined through luminescence measurements - Quaternary International 111. 91-100.

VÁRALLYAY G., 1967. A dunavölgyi talajok sófelhalmozódási folyamatai. Agrokémia és Talajtan. 16. 327-356. 


\title{
Geochemical evaluation of shallow drillings at Bugac pilot area (Middle-Hungary)
}

\author{
*U. FÜGEDI, B. KERÉK, L. KUTI, G. HALUPKA
}

Mining and Geological Survey of Hungary, Budapest

Department of Applied and Environmental Geology

\section{Summary}

Bugac pilot area, that is nearly $50 \mathrm{~km}^{2}$, was studied by four shallow drillingprograms earlier. This article presents the results and the explanation of the analysis of the trace element-measurements coming from the sampling in 1998-99.

On the hills wind-blown sand and in the flat areas clayey fine silty sediments (mainly carbonate-mud) are dominant. Although the flat areas are closed drainage basins, the situation of the hills-flat areas are not stable, so the characteristic sediments are mixed up. In the groundwater under the flat areas and in the seasonal ponds on the surface of the flats, the solved ion- (salt-) content increase is caused by the evaporation. Based on the sedimentary- and microelement examinations two special environments are worthy of underlining, the recent/archive surfaces, characterised by higher rate of coarse sand and the carbonated fine grained sediments in the flats.

The correlation between the acid soluble ions and the carbonate content based on the Scheibler-method is weak in the case of the Bugac pilot area too. The $\mathrm{Cr} / \mathrm{Mo}$ correlation and amount are caused by artificial effect; the $\mathrm{Ca} / \mathrm{Sr}$ ratio is determined by biogenic processes connected to carbonate mud, and the high S-content of these muds is resulted from the evaporation. All the analysed elements can be found in much less concentration than in most part of Hungary, except the element group of carbonate-accumulation $\left(\mathrm{Ca}, \mathrm{Mg}, \mathrm{Sr}, \mathrm{Ba}, \mathrm{CO}_{3}{ }^{2-}, \mathrm{SO}_{4}{ }^{2-}, \mathrm{PO}_{4}{ }^{3-}\right)$. The soils of the pilot area (mainly the sandy soils) are moderately lack of copper and strongly lack of zinc.

Keywords: Bugac, trace elements, carbonates, element-correlation, microelement balance

\section{Tables and figures}

Table 1. Correlations between carbonate contents determined using the Scheibler method and acid-soluble $\mathrm{Ca}$ and $\mathrm{Mg}$ contents (Kendall's $\tau$ ). (1) Ion/mineral. (2) Calcite (Cc). (3) Dolomite (Dol).

Table 2. Statistical parameters of the sediment types $\left(\mathrm{g} \mathrm{t}^{-1}\right)$. (1) Lime sludge. (2) Clayey stone meal. (3) Shifting sand. (4) Sandy loess, loessy sand. (5) Loess. (6) Element. (7) Median. (8) Interquartile half-range

Table $3 a, b$. Expected values (median, $\mathrm{g} \mathrm{t}^{-1}$ ) of elements in different horizons, analysed using ICP. 
Figure 1. Location of the sampling area

Figure 2. Sampling area with the drilling network and geologically important vegetation types (1) Grassland. (2) Cultivated or uncultivated arable. (3) Marshland. (4) Salt affected soils. (5) Peat. (6) Forest. (7) Drilling point.

Figure 3. Linear regression between the acid-soluble ions (x axis) and Scheibler's carbonate content (y axis) with the trendline

Figure 4. Total carbonate content $(\mathrm{Cc}+\mathrm{Dol}, \%)$ determined using the Scheibler method ( $\mathrm{N}=1090)$. (1) Frequency (No.). (2) Calcite + Dolomite (\%).

Figure 5. Correlation between $\mathrm{Ca}$ and $\mathrm{Sr}$ on the Bugac sampling area $(\mathrm{N}=430)$.

Figure 6. Asymmetric distribution of elements in samples of sampling area 'Bugac' 